Araştırma Makalesi / Research Article

Kimya Mühendisliği /

Chemical Engineering

DOI: $10.21597 /$ jist.507181
Iğdır Üniversitesi Fen Bilimleri Enstitüsü Dergisi, 9(3): 1539-1550, 2019

Journal of the Institute of Science and Technology, 9(3): 1539-1550, 2019

\title{
Evaluation of Color and COD Removal by Fenton and Photo-Fenton Processes from Industrial Paper Wastewater
}

\author{
Şefika KAYA ${ }^{1}$, Yeliz AŞÇI ${ }^{1 *}$
}

\begin{abstract}
Advanced oxidation processes which produce hydroxyl radicals with high oxidation potential have come forward among the methods used in the treatment of industrial wastewaters containing organic pollutants that are difficult to biodegrade. The application of UV rays with the fentanyl reactivity showed that the organic material is more fragmented and the degradation rate is higher. In this study, Fenton process and photo-Fenton process were applied to industrial wastewater of paper. In experimental studies, optimum experimental parameters such as iron ion and hydrogen peroxide concentrations, $\mathrm{pH}$, temperature, reaction time, mixing speed and light intensity were determined and processes were compared. $70 \%$ color and 51\% chemical oxygen demand (COD) removal in the Fenton process; 96\% color and 90\% COD removal in the photo-Fenton process were obtained. The addition of UV radiation to the oxidation process resulted in better degradation of organic contaminants and enhanced color and COD removal efficiency. Although the optimum reaction time of the Fenton process was 120 minutes, the optimum reaction time of the photo-Fenton process was 60 minutes.
\end{abstract}

Keywords: Oxidation, Fenton, photo-Fenton, wastewater treatment.

\footnotetext{
${ }^{1}$ Şefika KAYA (Orcid ID: 0000-0001-8277-4365), Yeliz AŞÇI (Orcid ID: 0000-0001-5618-058X), Eskisehir Osmangazi University, Department of Chemical Engineering, Eskisehir, Turkey

* Sorumlu Yazar/Corresponding Author: Yeliz AŞÇI, e-mail: yelizbal26@gmail.com

This study is a part of Şefika KAYA's PhD thesis.

Geliş tarihi / Received: 02.01.2019

Kabul tarihi/Accepted: 23.03.2019
} 


\section{INTRODUCTION}

For many years, it has been difficult to achieve high yields at low cost using modern technologies for the treatment of industrial wastewater. For this reason, biological and physico-chemical treatment methods are the first choice. Most industrial wastewaters contain organic substances that degrade very slowly or are not biodegradable (Gagol et al., 2018). It is difficult to remove organic compounds which are resistant to biological treatment processes by conventional wastewater treatment methods. For this reason, advanced oxidation processes (AOPs) have become a new option method by providing high efficiency to reduce and even mineralize these organic pollutants. Further oxidation processes are highly effective in removing organic contaminants by oxidation reactions with hydroxyl radicals (Garcia-Segura et al., 2016).

The Fenton process is a homogeneous oxidation process that produces hydroxyl radicals $(\cdot \mathrm{OH})$ at acidic conditions (Türeli, 2008). Iron salts serve as a catalyst for the dissociation of hydrogen peroxide and produce the hydroxyl radical. The Fenton process reaction steps are shown below (Rahmani, 2017).

$$
\begin{aligned}
& \mathrm{Fe}(\mathrm{II})+\mathrm{H}_{2} \mathrm{O}_{2} \longrightarrow \mathrm{Fe}(\mathrm{III})+\cdot \mathrm{OH}+\mathrm{OH}^{-} \\
& \cdot \mathrm{OH}+\mathrm{Fe}(\mathrm{II}) \longrightarrow \mathrm{OH}^{-}+\mathrm{Fe}(\mathrm{III}) \\
& \mathrm{Fe}(\mathrm{III})+\mathrm{H}_{2} \mathrm{O}_{2} \longleftrightarrow \mathrm{Fe}-\mathrm{OOH}^{2+}+\mathrm{H}^{+} \\
& \mathrm{Fe}-\mathrm{OOH}{ }^{2+} \longleftrightarrow \mathrm{HO}_{2}+\mathrm{Fe}(\mathrm{II}) \\
& \mathrm{Fe}(\mathrm{II})+\mathrm{HO}_{2} \longrightarrow \mathrm{Fe}(\mathrm{II})+\mathrm{O}_{2}+\mathrm{H}^{+} \\
& \cdot \mathrm{OH}+\mathrm{H}_{2} \mathrm{O}_{2} \longrightarrow \mathrm{H}_{2} \mathrm{O}+\mathrm{HO}_{2}
\end{aligned}
$$

The produced $\mathrm{Fe}(\mathrm{III})$ ions react with hydrogen peroxide and are reduced again to $\mathrm{Fe}(\mathrm{II})$ ion (Garrido-Ramirez et al., 2010). The photo-Fenton process is an AOPs in which
$\mathrm{Fe}(\mathrm{II}), \mathrm{H}_{2} \mathrm{O}_{2}$ and UV rays are applied together. The following two reactions produce $\cdot \mathrm{OH}$ radicals.

$$
\begin{array}{ll}
\mathrm{Fe}(\mathrm{OH})^{2+}+h v \longrightarrow \mathrm{Fe}(\mathrm{II})+\cdot \mathrm{OH} & v<580 \mathrm{~nm} \\
\mathrm{H}_{2} \mathrm{O}_{2}+h v \longrightarrow 2 \cdot \mathrm{OH} & v<310 \mathrm{~nm}
\end{array}
$$

According to the Fenton process, the oxidation is faster because it produces more hydroxyl radicals. However, at the end of the reaction, the formation of sludge decreases as total iron use decreases (Pouran et al., 2015).

The paper industry is the most important wastewater sources in the world (Tambosi et al., 2006). The amount of wastewater produced during the paper production process is approximately $75-225 \mathrm{~m}^{3} /$ ton. The resulting brown wastewater has high COD (Ginni et al., 2013). In studies carried out up to now, paper industries have found that lignin, stilbene, phenol, dioxin, chloride, furan, phenol and sulfur, etc. in wastewater. More than 250 different pollutants have been identified (Toczylowska-Maminska, 2017). 
In this study, it was aimed to treat paper industrial wastewater by AOPs. For this purpose, the optimum experimental conditions were determined by examining the influences of the parameters such as iron ion and hydrogen peroxide concentrations, $\mathrm{pH}$, temperature, reaction time, mixing speed and light intensity. Fenton and photo-Fenton processes have been compared to find out which method is more advantageous in paper industrial wastewater treatment. In the end, the highest color and COD removal were reached when the photo-Fenton process was applied.

\section{MATERIALS AND METHODS}

\section{Materials}

In the experimental studies paper industry wastewater was used. The wastewater was obtained from a manufacturing enterprise that produces bleached cellulose from scrap paper. The initial values of the wastewater were given in Table 1. Hydrogen peroxide (30\% w/w) and sodium hydroxide were supplied by Sigma Aldrich. Iron sulphate hepta hydrate and sulfuric acid were supplied by Merck.

Table 1. The characteristics of wastewater.

\begin{tabular}{cc}
\hline The characteristic & Value \\
\hline $\mathrm{pH}$ & 6.5 \\
COD $(\mathrm{mg} / \mathrm{l})$ & 6320 \\
Color $(\mathrm{Abs})$ & 1.23 \\
$\lambda_{\max }(\mathrm{nm})$ & 365.6 \\
TSS (mg/l) & 263 \\
\hline
\end{tabular}

\section{Experimental study of Fenton process}

In the Fenton process experimental studies, the $\mathrm{pH}$ value of the wastewater sample was adjusted by using $2 \mathrm{M} \mathrm{H} \mathrm{H}_{2} \mathrm{SO}_{4}$ solution. The $\mathrm{FeSO}_{4} \cdot 7 \mathrm{H}_{2} \mathrm{O}$ solution was added to the sample at the desired concentration. Then the $\mathrm{H}_{2} \mathrm{O}_{2}$ solution was added to the sample and the fenton reaction was started. The samples were agitated in the shaking water bath at constant temperature for a predetermined period of time. The $\mathrm{pH}$ of the samples was adjusted to 8 by addition of $2 \mathrm{M}$ $\mathrm{NaOH}$ solution to form the precipitate by terminating the reaction. At the end of the precipitation process, clear solution was taken and required analyzes were made.

\section{Experimental study of photo-Fenton process}

Photo-Fenton process experiments were actualized in the photoreactor (Kerman UV 188) device. The photoreactor was made of stainless steel material with an inside diameter of $285 \mathrm{~mm}$ and a height of $400 \mathrm{~mm}$. There were 18 UV (365nm) lamps each of $8 \mathrm{~W}$ in intensity. The unit can operate in three stages and has a total of $144 \mathrm{~W}$ operating characteristics. The device has a timer, a magnetic stirrer and an air circulation motor.

Experimental studies have used a quartz glass beaker and conducted a total solution volume of $200 \mathrm{ml}$. The $\mathrm{pH}$-adjusted wastewater sample was placed in the photoreactor device. The sample was firstly $\mathrm{FeSO}_{4} \cdot 7 \mathrm{H}_{2} \mathrm{O}$ solution, then $\mathrm{H}_{2} \mathrm{O}_{2}$ solution was added and UV lamps were opened. At the end of the experiment, precipitation was carried out and clear solution was analyzed.

\section{Analysis}

Wavelength and maximum absorbance values of the wastewater sample were 
determined by scanning in the spectrophotometer (Hach Lange DR 3900) in color analysis. For the paper industry wastewater, measurements of $365.6 \mathrm{~nm}$ wavelength were performed and color removal efficiency was calculated. In COD analysis, COD test kits were used. $2 \mathrm{ml}$ of samples were put into kits and kept in Hach Lange LT 200 brand thermoreactor for 2 hours at $148^{\circ} \mathrm{C}$. Then, spectrophotometer measurements were made. Total suspended solid (TSS) analysis was performed on spectrophotometer device using 25 $\mathrm{ml}$ square cuvettes. There was a program for TSS analysis in the spectrophotometer.

\section{RESULTS AND DISCUSSION}

\section{Effect of the $\mathrm{Fe}$ (II) concentration}

The concentration values of iron ion concentration in processes were determined according to the COD value of waste water $(\mathrm{Fe}(\mathrm{II}) / \mathrm{COD}=1 / 10-50(\mathrm{w} / \mathrm{w})$, (Bishop et al., 1968)). 18 UV lamps were used in photo-Fenton experimental studies. The results obtained were given in Fig. 1 and Fig. 2.

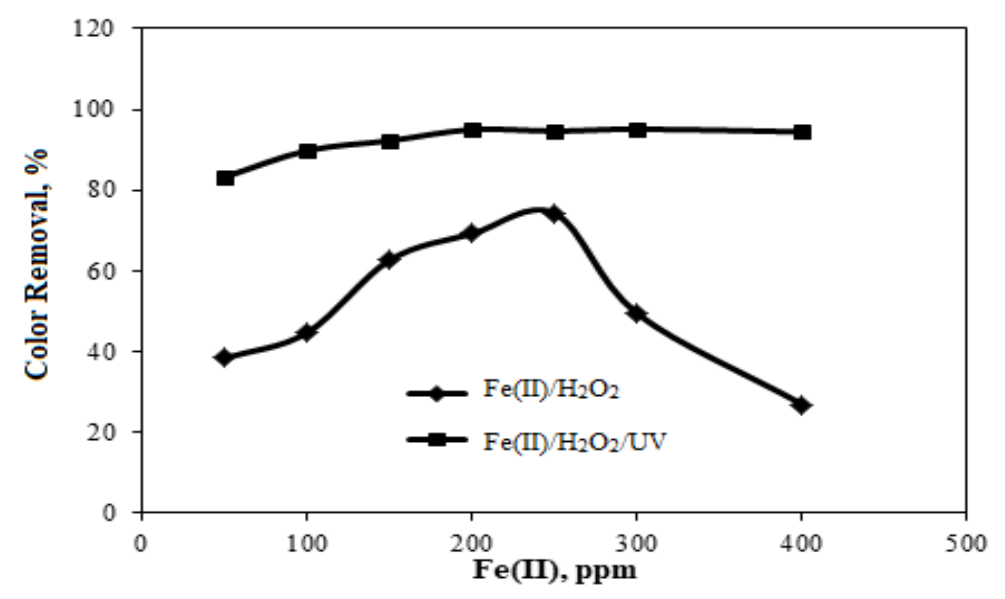

Figure 1. Effects of the $\mathrm{Fe}(\mathrm{II})$ concentration on color removal ( $\mathrm{pH}=2, \mathrm{H}_{2} \mathrm{O}_{2}=200 \mathrm{ppm}$, temperature $30^{\circ} \mathrm{C}$, reaction time 2 hours).

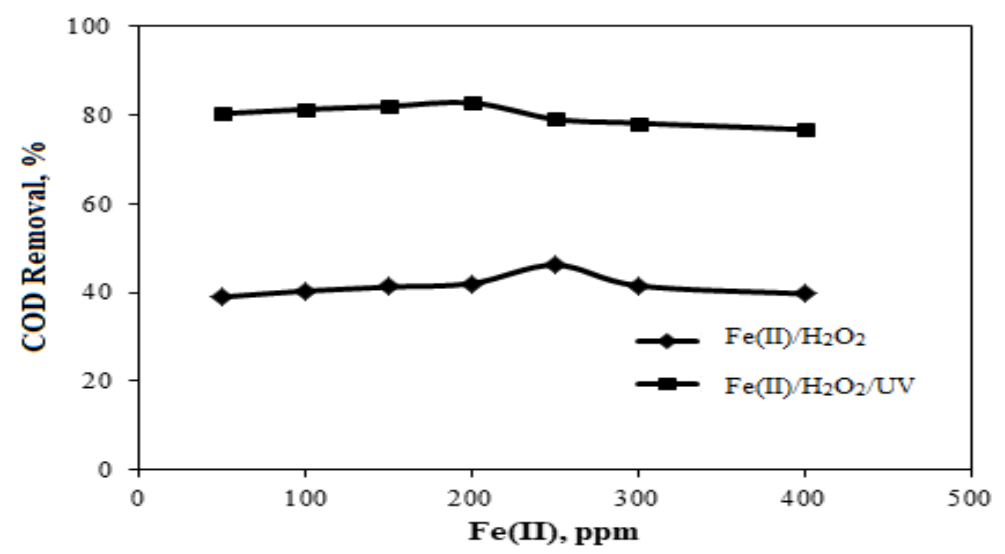

Figure 2. Effects of the $\mathrm{Fe}(\mathrm{II})$ concentration on $\mathrm{COD}$ removal $\left(\mathrm{pH}=2, \mathrm{H}_{2} \mathrm{O}_{2}=200 \mathrm{ppm}\right.$, temperature $30^{\circ} \mathrm{C}$, reaction time 2 hours).

When the experimental results obtained from the Fenton and photo-Fenton processes wastewater were analyzed, it was concluded that the removal efficiency of the photo-Fenton method was higher. Color and COD removal efficiencies were increased by using UV light. Higher removal results have been achieved at lower iron ion concentration in photo-Fenton process. When the iron ion concentration was $250 \mathrm{ppm}$, the maximum color and COD removal 
for the Fenton process were obtained as $74.23 \%$ and $46.20 \%$, respectively. $95.02 \%$ color and $82.79 \%$ COD removal efficiencies were achieved at $200 \mathrm{ppm}$ iron ion concentration in the photo-Fenton process. With the increase of iron ion concentration in the photo-Fenton process, the removal efficiencies increased and then remained stable. However, in the Fenton process, the increase of iron ion concentration has a negative effect on the color removal.

Chan and Chu (2003) emphasized that the study conducted by them had little effect on the oxidation capacity of high iron ion concentration, but that the low iron ion concentration was more critical to initiate the oxidation reaction. In the case of low iron ion concentrations, less hydroxyl radicals will be formed in the environment and no effective reaction occurs. However, high concentration of iron ions has a scavenging effect on hydroxyl radicals so color and COD removal efficiencies are affected negatively (Ayodele et al., 2012; Zhang et al., 2016).

\section{Effect of the pH}

The experimental studies were performed at $\mathrm{pH}$ values of 1.5, 2, 3, 4, 5 with fixed iron ion concentration, $\mathrm{H}_{2} \mathrm{O}_{2}$ concentration and reaction time constant. Figure 3 and Figure 4 showed the results.

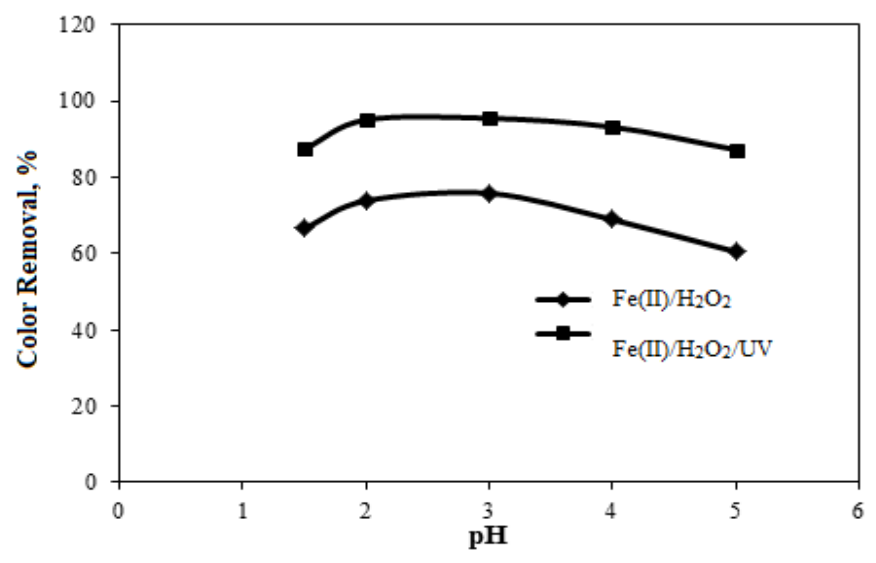

Figure 3. Effects of the $\mathrm{pH}$ on color removal $(\mathrm{Fe}(\mathrm{II})=250 \mathrm{ppm}$ for the Fenton process-Fe(II) $=200$ ppm for the photo-Fenton process, $\mathrm{H}_{2} \mathrm{O}_{2}=200 \mathrm{ppm}$, temperature $30^{\circ} \mathrm{C}$, reaction time 2 hours).

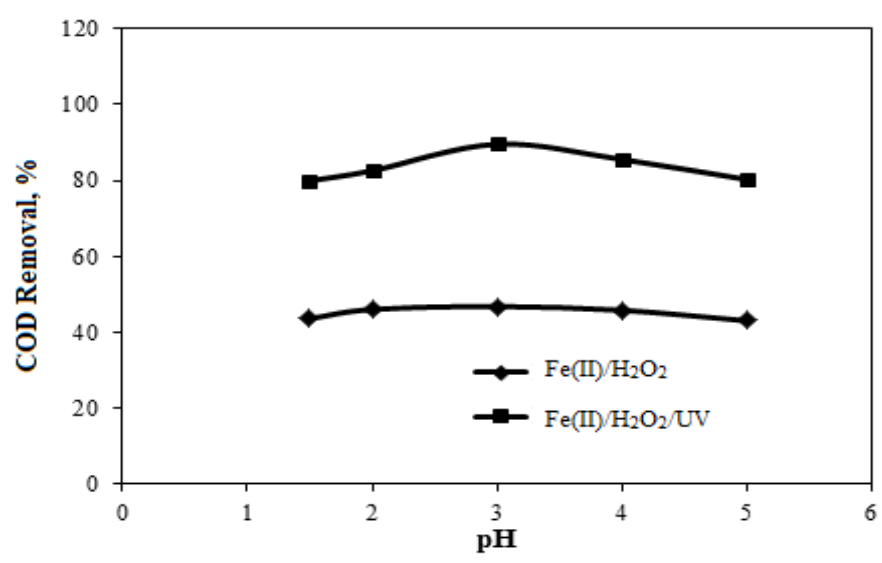

Figure 4. Effects of the $\mathrm{pH}$ on COD removal $(\mathrm{Fe}(\mathrm{II})=250 \mathrm{ppm}$ for the Fenton process-Fe(II) $=200$ ppm for the photo-Fenton process, $\mathrm{H}_{2} \mathrm{O}_{2}=200 \mathrm{ppm}$, temperature $30^{\circ} \mathrm{C}$, reaction time 2 hours). 
The optimum $\mathrm{pH}$ value for both oxidation processes was determined as 3 . As the $\mathrm{pH}$ value increased, the color and COD removal efficiencies were reduced as the iron ion lost its activity. Cruz et al. (2012) indicated that the optimum $\mathrm{pH}$ range for the activity of AOPs for aqueous solutions containing organic substances was usually $2<\mathrm{pH}<4$ and the optimal $\mathrm{pH}$ value was 3. Basturk and Karatas (2014) reported the $\mathrm{pH}$ value of 3 as the most appropriate in the study of the similar Fenton process. Wang and Shih (2015) reached maximum results at $\mathrm{pH} 3$ in their study for the degradation of the diazinon pesticide.

\section{Effect of the hydrogen peroxide concentration}

As shown in Fig. 5 and Fig. 6, the experimental studies were carried out at different hydrogen peroxide values between 50 and 400 ppm.

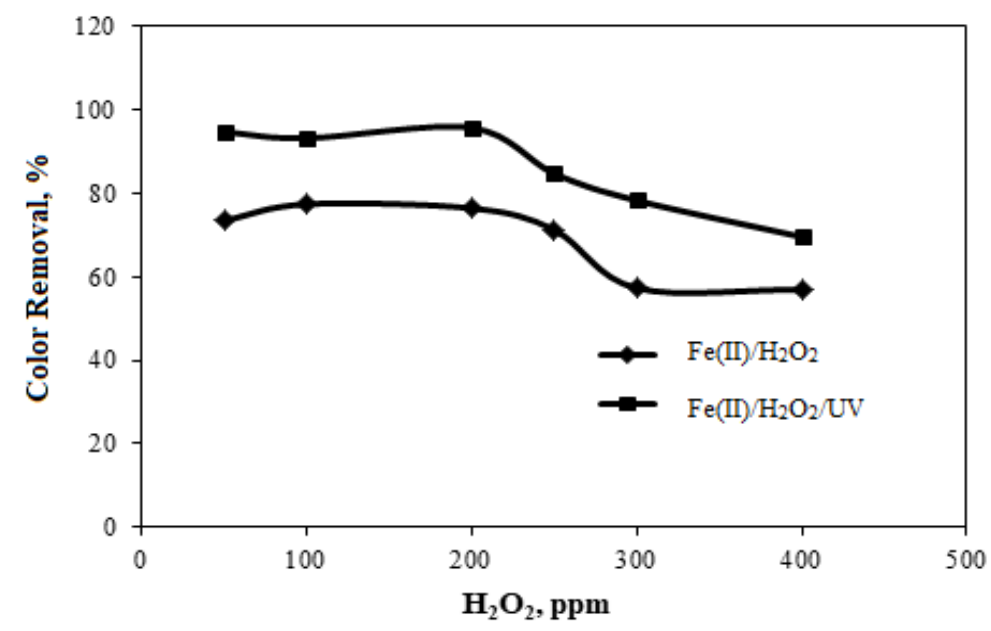

Figure 5. Effects of the $\mathrm{H}_{2} \mathrm{O}_{2}$ concentration on color removal $(\mathrm{Fe}(\mathrm{II})=250 \mathrm{ppm}$ for the Fenton process $-\mathrm{Fe}(\mathrm{II})=200 \mathrm{ppm}$ for the photo-Fenton process, $\mathrm{pH}=3$, temperature $30^{\circ} \mathrm{C}$, reaction time 2 hours).

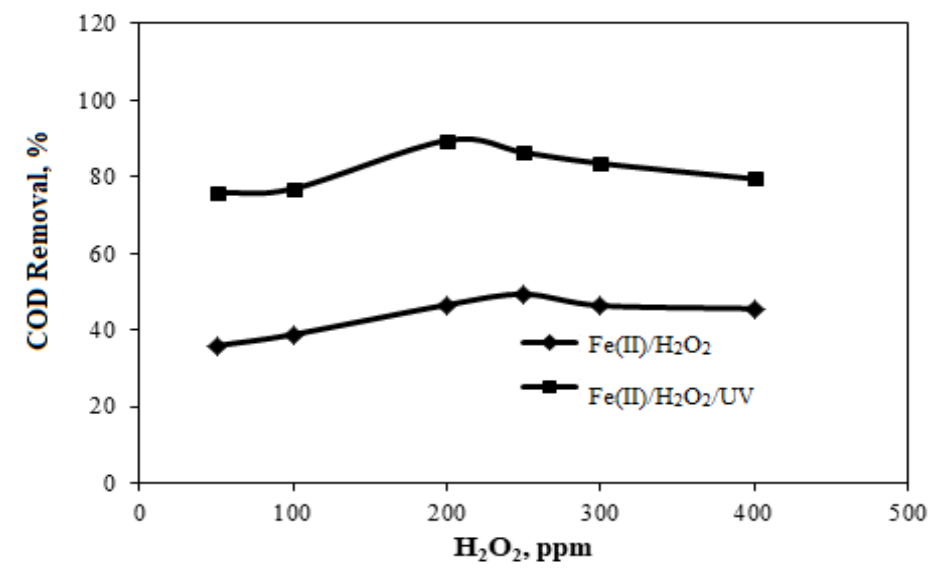

Figure 6. Effects of the $\mathrm{H}_{2} \mathrm{O}_{2}$ concentration on COD removal ( $\mathrm{Fe}(\mathrm{II})=250 \mathrm{ppm}$ for the Fenton process-Fe(II)=200 ppm for the photo-Fenton process, $\mathrm{pH}=3$, temperature $30^{\circ} \mathrm{C}$, reaction time 2 hours).

Since hydrogen peroxide is the source of hydroxyl radicals, it plays an important role in the degradation of organic compounds. When the concentration of hydrogen peroxide in the environment increases, the treatment efficiency increases. But excessive use of hydrogen peroxide causes reaction with the hydroxyl radicals in the environment and inhibits the oxidation reaction, leading to a reduction of the yield ( $\mathrm{Cu}$ et al., 2012). Fig. 5 and Fig. 6 are 
examined that the optimum concentration of hydrogen peroxide was determined to be 250 ppm for the Fenton process and 200 ppm for the photo-Fenton process.

\section{Effect of the temperature}

Under the optimum experimental conditions determined in experimental studies, it was carried out at seven different temperatures in the range of $20-50^{\circ} \mathrm{C}$. Since the temperature of the photoreactor device was not adjusted, only the effect of temperature on the Fenton process was examined. The results were shown in Fig. 7.

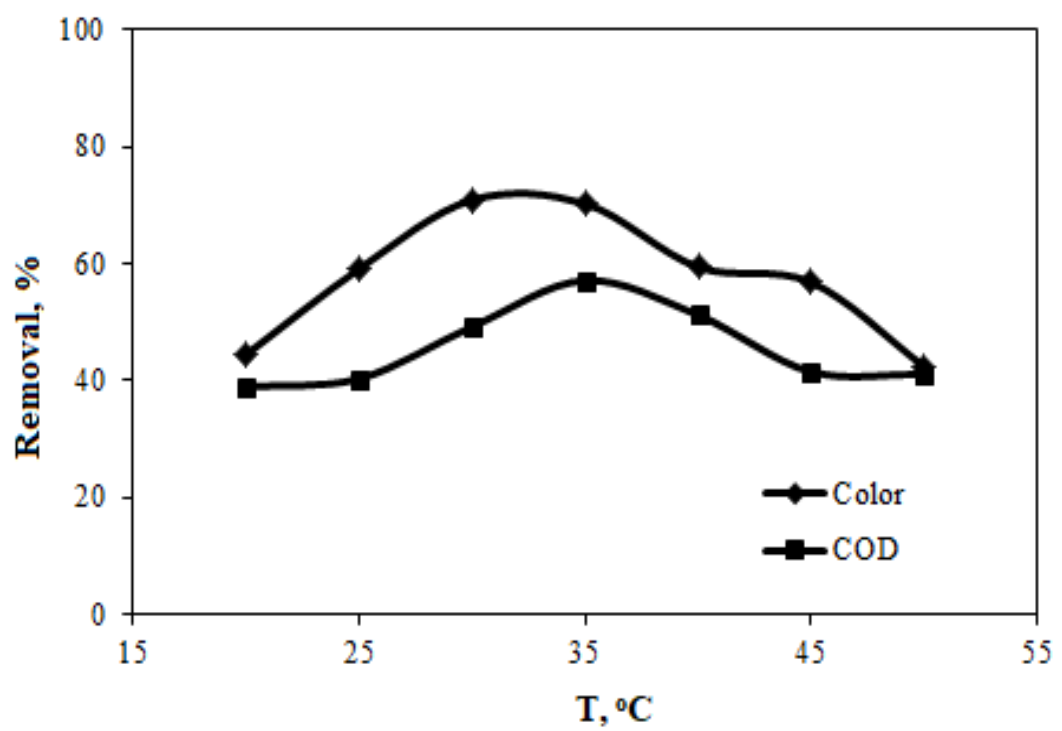

Figure 7. Effects of the temperature on color and COD removal ( $\mathrm{Fe}(\mathrm{II})=250 \mathrm{ppm}, \mathrm{pH}=3, \mathrm{H}_{2} \mathrm{O}_{2}=250 \mathrm{ppm}$, reaction time 2 hours).

Temperature change has had a similar effect on color and COD removal. With increasing temperature value, removal efficiency has begun to decrease after increasing the best value of $35^{\circ} \mathrm{C}$. Blanco et al. (2014) stated the best temperature value at $35^{\circ} \mathrm{C}$ in a similar study. In the study of Ünnü (2014), it has been reported that $\mathrm{H}_{2} \mathrm{O}$ and $\mathrm{O}_{2}$, which are the result of decomposition of hydrogen peroxide during the oxidation reactions during high temperatures, have a sweeping effect and therefore it is not appropriate to work at temperatures above $60^{\circ} \mathrm{C}$.

\section{Effect of the reaction time}

Experimental studies for the reaction time have been carried out for both processes. As shown in Fig. 8 and Fig. 9, experimental studies are carried out at different values between 5 minutes and 240 minutes of reaction time.

In the photo-Fenton process, hydroxyl radicals are produced by the beam source as well as the iron ion. For this reason, there are more hydroxyl radicals in the environment than the Fenton process and the oxidation rate is accelerated (Pouran et al., 2015). In the Fenton process $70.07 \%$ color and $56.88 \%$ COD removal were achieved in the reaction time of 120 minutes; high yield values such as $96.33 \%$ color and $90.43 \%$ COD removal in the reaction time of 60 minutes in the photo-Fenton process were reached. 


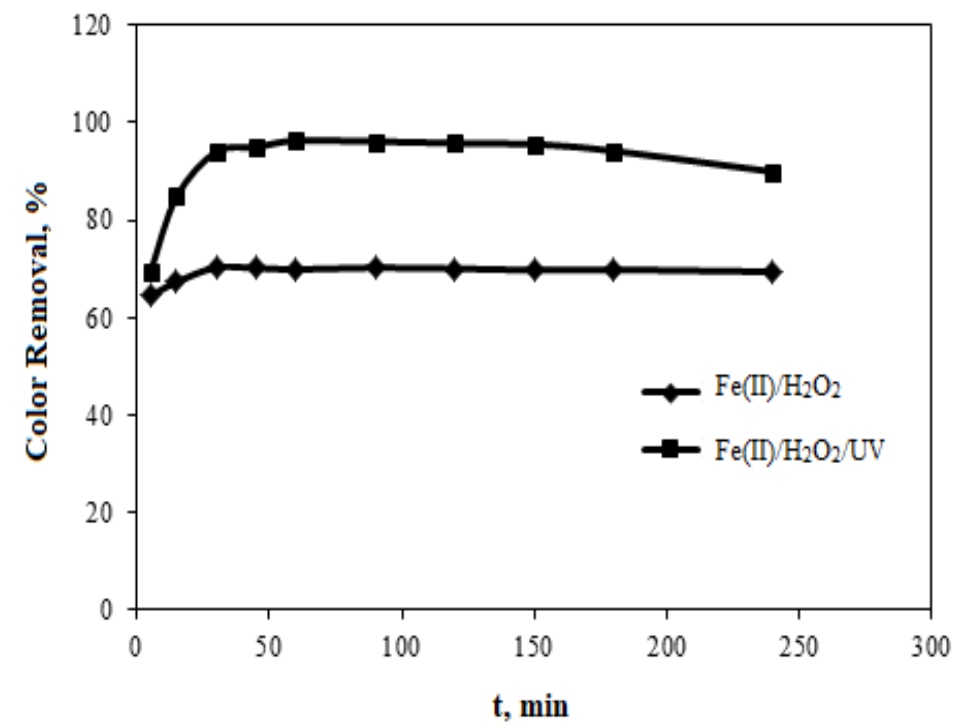

Figure 8. Effects of the reaction time on color removal $(\mathrm{Fe}(\mathrm{II})=250 \mathrm{ppm}$ for the Fenton process-Fe(II) $=200$ ppm for the photo-Fenton process, $\mathrm{pH}=3, \mathrm{H}_{2} \mathrm{O}_{2}=250 \mathrm{ppm}$ for the Fenton process $-\mathrm{H}_{2} \mathrm{O}_{2}=200 \mathrm{ppm}$ for the photo-Fenton process temperature $35^{\circ} \mathrm{C}$ ).

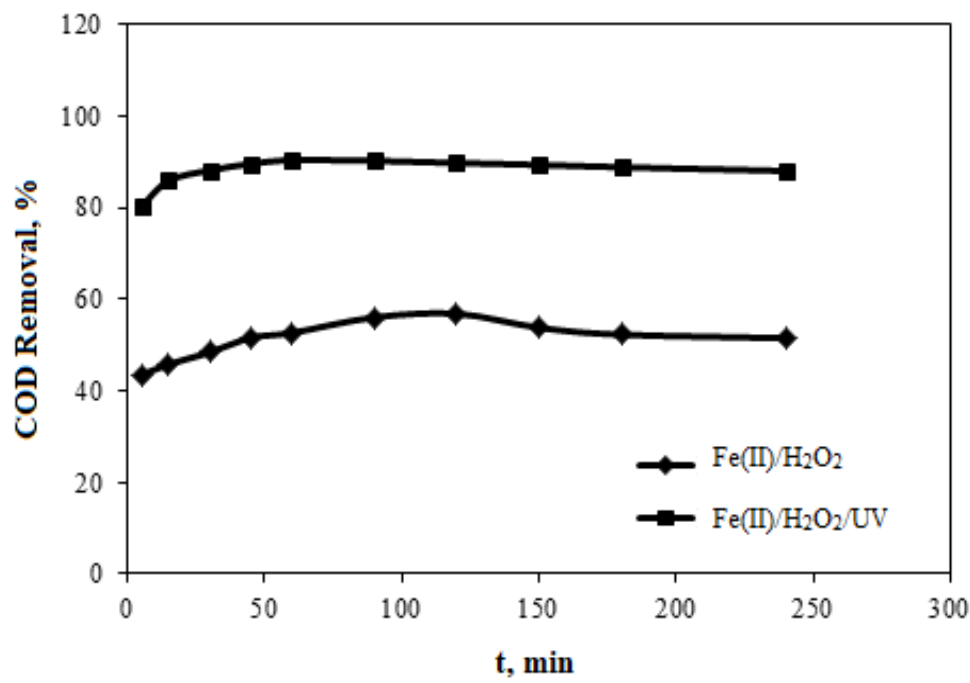

Figure 9. Effects of the reaction time on COD removal $(\mathrm{Fe}(\mathrm{II})=250 \mathrm{ppm}$ for the Fenton process-Fe(II)=200 ppm for the photo-Fenton process, $\mathrm{pH}=3, \mathrm{H}_{2} \mathrm{O}_{2}=250 \mathrm{ppm}$ for the Fenton process $-\mathrm{H}_{2} \mathrm{O}_{2}=200 \mathrm{ppm}$ for the photo-Fenton process temperature $35^{\circ} \mathrm{C}$ ).

\section{Effect of the mixing speed}

The effect of mixing speed on removal efficiency was investigated only for the experimental studies of the Fenton process. The mixing speed in the photoreactor was not adjustable. In the experimental studies, three different mixing speeds were used to determine the effect of mixing speed, and the results obtained are given below in Fig. 10.

Resulting in increased color and COD removal as homogeneous reactant distribution was achieved with increasing mixing speed. $70.23 \%$ color and $56.72 \%$ COD removal at 160 rpm, the optimum mixing speed, were obtained.

\section{Effect of the light intensity}

The effect of light intensity has only been achieved for experimental studies of the photoFenton process. Since the photoreactor can operate in three stages, 6, 12, 18 UV lamps have been operated in Fig. 11. 


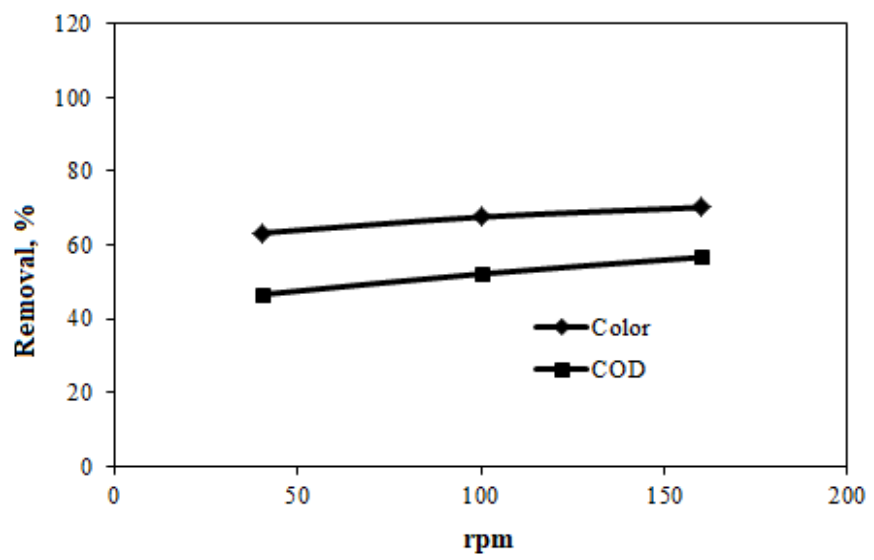

Figure 10. Effects of the mixing speed on color and COD removal $\left(\mathrm{Fe}(\mathrm{II})=250 \mathrm{ppm}, \mathrm{pH}=3, \mathrm{H}_{2} \mathrm{O}_{2}=250\right.$ ppm, temperature $35^{\circ} \mathrm{C}$, reaction time 2 hours).

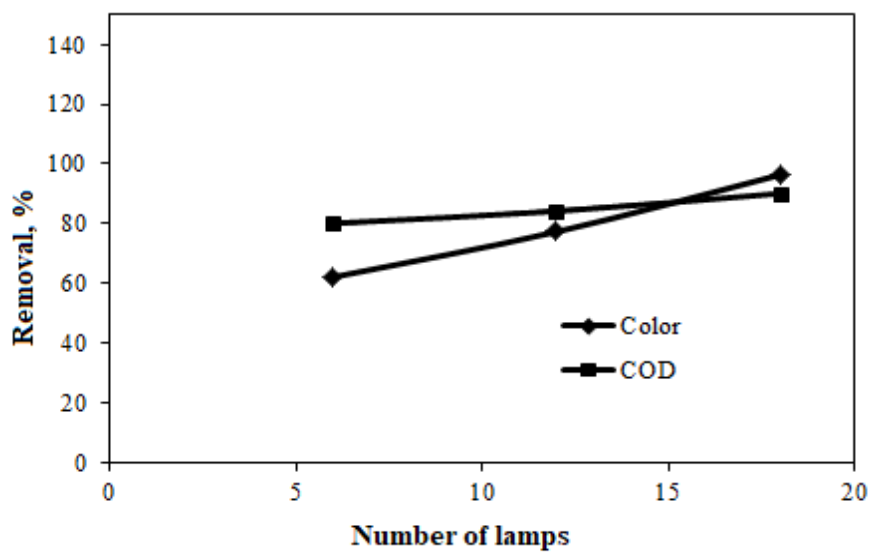

Figure 11. Effects of the light intensity on color and COD removal $\left(\mathrm{Fe}(\mathrm{II})=200 \mathrm{ppm}, \mathrm{pH}=3, \mathrm{H}_{2} \mathrm{O}_{2}=200\right.$ ppm, temperature $35^{\circ} \mathrm{C}$, reaction time 60 minutes).

The increase in light intensity is known to increase the production of hydroxyl radicals. When the results obtained with triple-headed (6; 12 ; 18) UV lamps were examined, it was seen that the maximum elimination was obtained when 18 UV lamps were used.

\section{TSS and COD analysis results}

TSS analysis was performed on a spectrophotometer device using $25 \mathrm{ml}$ square cuvettes. Test kits were used in COD analysis and measurements were made on spectrophotometer. The TSS and COD values of the samples which were in optimum experimental conditions determined by experimental studies were determined and given in Table 2.
When the experimental results were examined, it was seen that the TSS was removed by the AOPs. In the Regulation on Water Pollution Control, the suspended solids discharge limit value for the paper industry is 80 $\mathrm{mg} / \mathrm{l}$ and and the COD discharge limit is 870 $\mathrm{mg} / \mathrm{l}$. When the photo-Fenton process was applied, values lower than the discharge value for both TSS and COD have been reached. The Fenton process only provided the discharge limits for the TSS.

\section{Compare of optimum conditions with literature}

Table 3 shows the optimum conditions and removal percentages of similar studies with paper industry wastewater. 
Table 2. TSS analysis results.

\begin{tabular}{ccc}
\hline Process & TSS, $\mathbf{m g} / \mathbf{l}$ & COD, $\mathbf{~ m g / l}$ \\
\hline Fenton & 1 & 3097 \\
Photo-Fenton & 0 & 632 \\
\hline
\end{tabular}

Table 3. Compare of optimum conditions with literature.

\begin{tabular}{|c|c|c|c|c|c|c|c|c|}
\hline Treatment & $\begin{array}{l}\text { Initial } \\
\text { COD, } \\
\mathrm{mg} / \mathrm{l}\end{array}$ & pH & $\begin{array}{c}\text { Iron ion } \\
\text { concentration, } \\
\text { ppm }\end{array}$ & $\begin{array}{c}\mathbf{H}_{2} \mathbf{O}_{2} \\
\text { concentration, } \\
\text { ppm }\end{array}$ & $\begin{array}{c}\text { Time, } \\
\text { min }\end{array}$ & $\begin{array}{c}\text { Color } \\
\text { Removal, } \\
\%\end{array}$ & $\begin{array}{c}\text { COD } \\
\text { Removal, } \\
\%\end{array}$ & Reference \\
\hline $\begin{array}{l}\text { Photo- } \\
\text { Fenton }\end{array}$ & - & 5 & 140 & 1700 & 30 & 82.5 & - & $\begin{array}{l}\text { (Catalkaya } \\
\text { and Kargi, } \\
\text { 2006) }\end{array}$ \\
\hline $\begin{array}{l}\text { Photo- } \\
\text { Fenton }\end{array}$ & 964 & 2.5 & 400 & 1000 & 60 & 98 & 75 & $\begin{array}{l}\text { (Tambosi } \\
\text { et al., 2006) }\end{array}$ \\
\hline $\begin{array}{l}\text { Photo- } \\
\text { Fenton }\end{array}$ & 10300 & 3 & 500 & 1500 & 45 & - & 79.6 & $\begin{array}{l}\text { (Jamil et } \\
\text { al., 2011) }\end{array}$ \\
\hline $\begin{array}{l}\text { Photo- } \\
\text { Fenton }\end{array}$ & 530 & 2.8 & 120 & 1200 & - & - & 80 & $\begin{array}{l}\text { (Hermosilla } \\
\text { et al., 2012) }\end{array}$ \\
\hline Fenton & 436 & 3.8 & 1147 & 517 & 60 & - & 63 & $\begin{array}{l}\text { (Brink et } \\
\text { al., 2017) }\end{array}$ \\
\hline Fenton & 9992 & 3 & 5700 & 20000 & 120 & - & 52 & $\begin{array}{l}\text { (Grötzner } \\
\text { et al., 2018) }\end{array}$ \\
\hline Fenton & - & 3 & 100 & 600 & 300 & 98 & 62 & $\begin{array}{l}\text { (Kazmi and } \\
\text { Thul, 2007) }\end{array}$ \\
\hline $\begin{array}{l}\text { Photo- } \\
\text { Fenton }\end{array}$ & 6320 & 3 & 200 & 200 & 60 & 96 & 90 & Our study \\
\hline
\end{tabular}

As shown in Table 3, the initial COD value of the wastewater we use in our study was quite high. The optimum $\mathrm{pH}$ value was consistent with the literature and the optimum $\mathrm{H}_{2} \mathrm{O}_{2}$ concentration was quite low. This provides less chemical use than other studies.

As a result, the color and COD removal results obtained for the photo-Fenton process in the optimum conditions determined were considerably higher than the other studies. This means that the method is suitable for the paper industry wastewater treatment.

\section{CONCLUSION}

Applying the Fenton and photo-Fenton proceses have compared in the paper industrial wastewater removal studies. The optimum conditions in the Fenton process experimental studies were determined as iron ion concentration $250 \mathrm{ppm}, \mathrm{pH}=3$, hydrogen peroxide concentration $250 \mathrm{ppm}$, temperature $35^{\circ} \mathrm{C}$, reaction time 120 minutes and mixing speed $160 \mathrm{rpm}$. Under these conditions, 70\% color and 57\% COD removal efficiencies were achieved. Optimal conditions for the photoFenton process were $200 \mathrm{ppm}$ of iron ion concentration, $\mathrm{pH}=3$, hydrogen peroxide concentration of $200 \mathrm{ppm}$, reaction time of 60 minutes and 18 lamps as optimum conditions. Under these conditions, 96\% color and 90\% COD removal efficiencies were achieved. The photo-Fenton process produces more hydroxyl radicals in the presence of UV light than the Fenton process and the total iron ion use is less. For this reason, the oxidation rate is higher in photo-Fenton process and the formation of 
sludge is less due to the less use of iron ions. As a result, we can conclude that the photo-Fenton process can be a suitable method for high color and COD removal in wastewater treatment.

\section{ACKNOWLEDGMENT}

Eskişehir Osmangazi University Scientific Research Projects Commission supported this study as project number 201615059.

\section{REFERENCES}

Ayodele OB, Lim JK, Hameed BH, 2012. Pillared montmorillonite supported ferric oxalate as heterogeneous photo-Fenton catalyst for degradation of amoxicillin. Applied Catalysis, 413-414: 301-309.

Basturk E, Karatas M, 2014. Advanced oxidation of Reactive Blue 181 solution: A comparison between Fenton and SonoFenton Process. Ultrasonics Sonochemistry, 21: 1881-1885.

Bishop DF, Stern G, Fleischman M, Marshall LS, 1968. Hydrogen peroxide catalytic oxidation of refractory organics in municipal waste waters. Industrial\&Engineering Chemistry Process Design and Development, 7: 110-170.

Blanco J, Torrades F, Morón M, Brouta-Agnésa M, García-Montaño J, 2014. Photo-Fenton and sequencing batch reactor coupled to photo-Fenton processes for textile wastewater reclamation: Feasibility of reuse in dyeing processes. Chemical Engineering Journal, 240: 469-475.

Brink A, Sheridan CM, Harding KG, 2017. The Fenton oxidation of biologically treated paperand pulp mill effluents: A performance andkinetic study. Process Safety and Environmental Protection, 107, 206-215.

Catalkaya EC, Kargi F, 2007. Color, TOC and AOX removals from pulp mill effluent by advanced oxidation processes: A comparative study. Journal of Hazardous Materials, B139, 244-253.
Chan K, Chu W, 2003. The dose and ratio effects of $\mathrm{Fe}(\mathrm{II})$ and $\mathrm{H}_{2} \mathrm{O}_{2}$ in Fenton's process on the removal of atrazine. Environmental Technology, 24: 703-710.

Cruz ND, Gimenez J, Esplugas S, Grandjean D, Alencastro LF, Pulgarin C, 2012. Degradation of 32 emergent contaminants by UV and neutral photo-fenton in domestic wastewater effluent previously treated by activated sludge. Water Research, 46: 1947-1957.

Chu L, Wanga J, Dong J, Liu H, Sun X, 2012. Treatment of coking wastewater by an advanced Fenton oxidation process using iron powder and hydrogen peroxide. Chemosphere, 86: 409-414.

Gagol M, Przyjazny A, Boczkaj G, 2018. Wastewater Treatment by Means of Advanced Oxidation Processes Based on Cavtation-A Review. Chemical Engineering Journal, 338: 599-627.

Garcia-Segura S, Bellotindos LM, Huang Y, Brillas E, Lu M, 2016. Fluidized-bed Fenton process as alternative wastewater treatment technology-A review. Journal of the Taiwan Institute of Chemical Engineers, 67: 211-225.

Garrido-Ramirez EG, Theng BKG, Mora ML, 2010. Clays and oxide minerals as catalysts and nanocatalysts in Fenton-like reactions - A review. Applied Clay Science, 47: 182-192.

Ginni G, Adishkumar S, Banu RJ, Yogalakshmi N, 2013. Treatment of pulp and paper mill wastewater by solar photo-Fenton proces. Desalination and Water Treatment, 52: 2457-2464.

Grötzner M, Melchiors E, Schroeder LH, Santos A., Moscon KG, Andrade MA, Martinelli SHS, Xavier CR, 2018. Pulp and Paper Mill Effluent Treated by Combining Coagulation-Flocculation-Sedimentation and Fenton Processes, Water Air Soil Pollution, 229: 364. 
Hermosilla D, Merayo N, Ordonez R, Blanco A, 2012. Optimization of conventional Fenton and ultraviolet-assisted oxidation processes for the treatment of reverse osmosis retentate from a paper mill. Waste Management, 32, 1236-1243.

Jamil TS, Ghaly MY, El-Seesy IE, Souaya ER, Nasr RA, 2011. A comparative study among different photochemical oxidation processes to enhance the biodegradability of paper mill wastewater. Journal of hazardous materials, 185, 353-358.

Kazmi AA, Thul R, 2007. Colour and COD removal from pulp and paper mill effluent by $\mathrm{q}$ Fenton's oxidation. Journal of Environmental Science and Engineering, 49, 189-94.

Pouran SR, Aziz ARA, Daud WMAW, 2015. Review on the main advances in photoFenton oxidation system for recalcitrant wastewaters. Journal of Industrial and Engineering Chemistry, 21: 53-69.

Rahmani A, 2017. Heterogeneous Fenton Oxidation Process Using Natural Martite And Hydrogen Peroxide For Treatment Of Color in Water. Middle East Technical University, Master Thesis (Printed).

Regulation on Water Pollution Control. 2004. Turkey Official Newspapers Number of 25687, $51 \mathrm{~s}$.

Tambosi JL, Domenico MD, Schirmer WN, Jose HJ, Moreira RF, 2006. Treatment of paper and pulp wastewater and removal of odorous compounds by a Fenton-like process at the pilot scale. Journal of Chemical Technology and Biotechnology, 81: 1426-1432.
Toczylowska-Maminska R, 2017. Limits and perspectives of pulp and paper industry wastewater treatment - A review. Renewable and Sustainable Energy Reviews, 78: 764-772.

Türeli G, 2008. Treatment of an Azo Dye and Azo Dye Production Wastewaters with Fenton-Like and Photo-Fenton-Like Advanced Oxidation Processes. İstanbul Technical University, Master Thesis (Printed).

Ünnü BA, 2014. Degradation of Crystal Violet Over Fe-ZSM-5 Zeolite Catalyst by Heterogeneous Fenton-Like Oxidation and/or Sonication. Ege University, Master Thesis (Printed).

Wang C, Shih Y, 2015. Degradation and detoxification of diazinon by sono-Fenton and sono-Fenton-like processes. Separation and Purification Technology, 140: 6-12.

Zhang A, Wang N, Zhou J, Jiang P, Liu G, 2012. Heterogeneous Fenton-like catalytic removal of p-nitrophenol in water using acid-activated fly ash. Journal of Hazardous Materials, 201-202: 68-73. 